\title{
An Insight into Sweet Potato Weevils Management: A Review
}

\author{
Seow-Mun Hue and Min-Yang Low \\ School of Science, Monash University Malaysia, 47500 Bandar Sunway, Selangor Darul Ehsan, Malaysia \\ Correspondence should be addressed to Seow-Mun Hue; hue.seow.mun@monash.edu \\ Received 7 July 2015; Accepted 21 September 2015 \\ Academic Editor: Nguya K. Maniania
}

Copyright (C) 2015 S.-M. Hue and M.-Y. Low. This is an open access article distributed under the Creative Commons Attribution License, which permits unrestricted use, distribution, and reproduction in any medium, provided the original work is properly cited.

Sweet potato is an important food crop that is grown widely in tropical and subtropical regions. Sweet potato weevil is the most disastrous pest affecting sweet potato plantations, causing millions of dollars losses annually. An effective integrated pest management (IPM) method will help to prevent economic losses, and it is crucial to understand the factors that contribute to weevil infestation and strategies that are available to overcome them. This review summarizes the (1) mechanisms of action of weevil on sweet potato and (2) contributing factors in weevil infestation, followed by (3) discussion on current IPM practices used in the different regions, including intercropping, entomopathogenic fungi and bacteria, sex pheromones, and pesticides. Lastly, it also focuses on (4) applications of advanced biotechnology and genomics strategies towards reducing weevil's infestation in sweet potato plantation.

\section{Introduction}

Sweet potato is currently ranked as the seventh most important crop in the world with a total production of 103 million tonnes in 2013 [1]. It is produced largely in Asia (accounting for up to $76.1 \%$ of world production in 2013), followed by the African continent (19.5\%) [1]. The top five producers of sweet potato in 2014 were China, Nigeria, Uganda, Indonesia, and the United Republic of Tanzania [1]. Sweet potato is one of the five most important crops in 40 developing countries besides rice, wheat, maize, and cassava [2]. Despite the crop's economic importance, widespread sweet potato weevil infestation results in losses of millions of dollars annually [3].

Since weevils are widely dispersed in tropical regions of the world, their management is the key issue faced by farmers in major sweet potato producing countries. The four main species of weevils that cause the most harm to sweet potato plantation are Euscepes postfasciatus (Fairmaire), Cylas formicarius (Fabricius), Cylas puncticollis (Boheman), and Cylas brunneus (Fabricius) [4,5]. Euscepes postfasciatus is a South American species that is more prevalent in Central and South America. Cylas formicarius is an Asian species but is usually found throughout the tropical regions worldwide including North America, the Caribbean, Europe, Africa,
Asia, and Oceania. Cylas brunneus and Cylas puncticollis are African species and are restricted to Africa. There are other species of sweet potato weevils in the tropical regions in Africa, for example, the rough sweet potato weevil (Blosyrus spp.) and striped sweet potato weevil (Alcidodes dentipes and Alcidodes erroneous), but their damage to sweet potato cultivation is not as severe as the main species (Cylas spp.) [6].

1.1. Sweet Potato Weevil Infestation by Regions. Sweet potato weevil is by far the most destructive pest of the sweet potato plant. The degree of infestation varies from region to region but weevils nevertheless cause severe damage to plantations. A research conducted by the Taiwan Agricultural Chemical and Toxic Substances Research Institute Council of Agriculture revealed that the damage caused by sweet potato weevil reduced sweet potato production in Taiwan by $1-5 \%$, while the damage in extensive commercial produced fields was up to $18 \%$ [7].

In China's Guangdong Province, yield generally shrunk by $5-20 \%$ and, in some cases, by up to $80 \%$ [8]. In Vietnam, farm-level plantations losses were documented to suffer up to $40 \%$ of reduction in yield [9]. Losses of $3-80 \%$ were recorded in Indonesia, throughout several locations and seasons [10] and with higher damage observed during the dry season [11]. 
In Malaysia, exact losses in the field were not recorded in recent years; the only documented figure was a 1970 study showing $80 \%$ yield loss or 4 tons/acre [12]. In the Philippines, sweet potato yield was reduced by $50 \%$ due to $C$. formicarius infestation [13], while in Japan (Amami Islands), losses were recorded at $15 \%$ [14].

Cylas spp. were found to be the major pest in the tropical regions in Africa. Losses were recorded to be as much as $73 \%$ in Uganda [15] depending on the planting period and 15-20\% in yield in Tanzania [16]. In other areas in the continent, losses have been shown to reach up to $100 \%[17,18]$.

In the United States, the southern states of Alabama, Louisiana, Mississippi, and North Carolina produce $75 \%$ of sweet potato supply [19]. While the main pests affecting sweet potato plantations in these regions include sweet potato weevils, wireworms, white grubs, sweet potato flea beetle, cucumber beetle, white fringed beetle, and sugarcane beetle, weevils cause the worst damage to this crop [19]. In Southern Florida, up to $80 \%$ (average $69 \%$ ) of losses in sweet potato yields have been reported, mainly contributed by the death of infested plants [20]. Due to the severity of this problem, several workshops were conducted by universities in this state to bring together all parties involved to develop plans for pest management in sweet potato production [19]. Through these activities, IPM strategies were implemented (such as pheromones trap and usage of selected approved pesticides); farmers were also given information about planting strategies (bedding and soil preparation) to minimise infestation and the introduction of sweet potato cultivar with higher resistance to weevils (such as Regal) [21].

In the Dominican Republic, sweet potato farm-level losses due to weevil infestation were estimated at 39\% [22]. Weevil is also found in all provinces of Cuba where sweet potato plantations are located and, in the absence of adequate control, losses have been shown to reach up to $45 \%$ [23].

1.2. Sweet Potato Weevil Mode of Action. Although different subspecies of sweet potato weevils can be found in different geographical locations, their modes of action remain the same [24]. Sweet potato weevils generally cause serious damage to all parts of sweet potato plant throughout their life cycle, from egg to adult. When laying eggs, female weevils excavate cavities and create egg-laying punctures in the roots. The eggs are laid below the surface of the roots and covered with dark colour excrement from the female adults [24]. As a result of the unsightly punctures, the appeal of the roots and market price of sweet potato become greatly reduced, resulting in major economic losses.

Hatching will generally occur in a week after oviposition by females. Hatched larvae will start making tunnels inside tubers and feed inside galleries [25]. The tunnels inside the tubers of sweet potatoes will be filled with excrement from the larvae. As the larvae feed, the sweet potato will impart a bitter flavour and terpene odour, making it unsuitable for the consumption of human or livestock. The presence of terpenoid reduces the marketable yield and root quality of sweet potatoes [26]. Mining of sweet potato tubers by larvae is the principal cause of sweet potato damage. The tuber becomes spongy in appearance, riddled with cavities, and dark in colour [26]. Beside that, larvae also mine into the vines of sweet potato, causing it to darken, crack, and collapse. Apparent symptoms of weevils infestation will be yellowing of the vines but this usually only occur after heavy infestation [26].

Larvae tunnelling inside the tubers will indirectly facilitate the entry of soilborne pathogens, which can cause further damage from secondary infections by fungi and bacteria [25]. In addition, the larvae will cause damage to the vascular system, which then reduces the number and size of future storage roots. Subsequently, adults will start emerging and will start feeding on leaves, vines, tender buds, and storage roots of sweet potato by punctuating the surface. Since most of the infestations generally occur below the soil level, these problems can go undetected until harvesting season arrives. Observations from the different regions of sweet potato plantations summarize the factors that can contribute to sweet potato weevil infestation. This information is important as a preventive measure against future infestation.

\section{Factors Influencing Sweet Potato Weevil Infestation}

2.1. Physical Attributes of Sweet Potato. Host plant resistance plays an important role in the management of serious insect pests [27]. Apart from the nutritional quality of its tuber, the physical attributes of sweet potato, including its flesh colour, neck length, shape, thickness, and skin colour, influence the infestation by sweet potato weevils. Oval- and roundshape sweet potato tubers were more severely infested by sweet potato weevils compared to elongate, spindle, and long stalked ones. Besides, cultivars with pink and red coloured tubers as well as lobed leaves and thin foliage were considered less susceptible compared to brown and white coloured tubers [28].

The level of infestation in the different sweet potato genotypes was reported to be related to the concentration of kairomones in the periderm of the tubers. For example, boehmeryl acetate, a kairomone identified in sweet potato tubers surface, acts as an ovipositional stimulant for female weevils [29]. This finding was supported by Nottingham et al. [30] who discovered triterpenol acetate on the root surface of the genotype "Centennial" which has shown similar function to other kairomones. This suggests that selection of sweet potato genotypes with increased deterrents or decreased concentration of kairomones such as boehmeryl acetate and triterpenol acetate may significantly facilitate sweet potato resistance to weevils [27]. Therefore, the selection of sweet potato variety is important for the control of sweet potato weevils.

Deep-rooting and early maturing varieties (90 to 120 days) are about four times less susceptible to infestation than shallow-rooting and late maturing varieties (180 days or more). As a result, both deep storage roots and early maturing varieties tend to reduce the severity of weevil damage [31]. More than $95 \%$ of oviposition by female weevils happens in the first $35 \mathrm{~cm}$ of vines and planting of infested cuttings is one of the ways of distributing sweet potato weevils [31]. Therefore, treatment of infested stem cuttings 
with insecticides or Beauveria bassiana is currently being practised to reduce weevil infestation.

2.2. Age of Stem Cutting. Female weevils tend to lay eggs in the older portions of vines, especially when they cannot access the roots or the storage roots are absent. Since planting of infested cuttings or vines will spread weevil infestation, weevil-free cuttings of sweet potato vines produced by dipping in an insecticide solution are recommended [32]. Older portions of cuttings are usually severely infested with weevils, while younger cuttings are rarely infested with weevils. This notion is supported by a field study, which showed increase in number of weevils in vines in increased vine age [33].

2.3. Altitude and Season. Weevil infestation has a strong relationship with the location altitude and planting season of sweet potato. Several studies have concluded that higher temperature may increase the growth rate of insect's population as well as the risk and severity of the outbreaks $[34,35]$. In Kerala, India, tuber damage by weevil infestation was observed to be less serious in lowland (up to 22\%) compared to upland (4 to 50\%) [36]. On the other hand, a study in Kabale District, Uganda, reported higher number of Cylas spp. infestation at lowland (up to 1814 meters above sea level) (77\%) compared to the number of Cylas spp. at higher altitude (1992-2438 meters above sea level) (23\%) [37]. The rate of infestation in this case may be also affected by other reasons such as method used in planting, sanitation level in that area, and the variety of sweet potato planted.

According to Bhat [38], the incidence of weevil infestation was higher when planting in the period from August to November $(87.4 \%)$ compared to the planting in the period from June to July (10.9\%). A study conducted in India showed that tuber damage was higher (71\%) during summer season (February-May) compared to monsoon season (June-September) (45\%) [36]. Thus, weevil infestation can be reduced by proper planning of planting and harvesting time as well as the planting location.

In addition, sweet potato weevil relies strongly on cracks in dry soil to reach the storage roots, as they cannot dig. Hence, weevils cannot reach roots which are well buried under the soil. The enlargement of roots near the soil surface and the stress from soil moisture can increase the chances of producing cracks and exposure of roots to the weevils. The incidence of damage caused by sweet potato weevils was observed to be lesser during wet season compared to dry season as the absence of cracks hinders weevils from accessing the roots [39-41].

\section{Current Strategies to Overcome Sweet Potato Weevil Infestation}

3.1. Mixed Cropping or Intercropping. Some farmers practise mixed cropping systems with sweet potato, rice, cowpea, maize, ginger, and yam to reduce the incidence of sweet potato weevils. Pillai et al. [42] reported that intercropping sweet potato with colocasia, rice, or cowpea resulted in up to tenfold reduction in the infestation of sweet potato weevil
(4.8-11.54 weevils per $\mathrm{kg}$ of tubers) compared to monocrop of sweet potato (217.5 weevils per kg of tubers) in Kerala, India.

Besides, effective crop rotations also resulted in lower tuber damage (ranged from 7 to 9\%) compared to monoculture of sweet potato (52\%) [43]. Crop rotation method was found to be effective in controlling weevil infestation as the number of weevils captured by sex pheromone traps in areas with monoculture of sweet potato exceeded exponentially compared to pheromone traps in areas planted with sweet potato rotated with potato [44].

Additional steps such as elimination of crop residues will also increase the effectiveness of IPM. For instance, a field sampling in Cuba showed that 0.7 tonnes of crop residues per hectare could harbour approximately one million weevils. Aside from this, new sweet potato plantings are also recommended to be separated from older fields (approximately $1 \mathrm{~km}$ ) as the risk of weevil infestation increases with the age of sweet potato fields. This distance length was chosen as the estimated dispersal ability of the weevils from invading a new plantation $[45,46]$. In Japan, alternative crops were suggested to farmers to be planted between sweet potato plantations, for example, yam (Dioscorea japonica), "senryo" (Chloranthus glaber), and edible sunflower [47].

3.2. Mulching, Irrigation, and Reridging. Since dry soil allows weevil to reach the target roots, an important strategy to deter infestation is by preventing soil cracking. This can be achieved by irrigating frequently or hilling a small area around the sweet potato plant in order to prevent the entry of weevils into the roots. An experiment was conducted by Talekar [48] to determine the potential of mulching materials such as rice straw and plastic film in reducing the infestation of sweet potato weevils by spreading them over the planting site of sweet potato. The result showed that rice straw and plastic film successfully reduced weevil infestation by $55 \%$ and $35 \%$, respectively. Mulching materials were found to minimize soil cracking and conserve soil moisture and provide a physical barrier that reduced the entry of weevils to roots.

Reridging is another approach that works to prevent the entry of weevils into tuber and oviposition by female weevils, but this works best only when performed at the tuber formation stage. Palaniswami and Mohandas [49] conducted a study in India to investigate the efficiency of reridging in sweet potato plant in reducing the infestation of weevils. It was observed that the weevil infestation was significantly reduced by this method.

Soil cracking due to deficiency in irrigation or drought will facilitate the entry of eggs into the roots. Therefore, in Cuba, sweet potato was commonly planted during rainy season because less irrigated fields were 4 to 5 times more infested with weevils compared to well-irrigated fields. Besides, weevil associated damage also increase by over 4 times if harvesting was delayed by 30 days; hence, it is necessary to harvest mature crops before the infestation level reached $3 \%[50,51]$.

3.3. Sanitation. Sanitation practices play a vital role in protecting sweet potato from pests with limited flying capacity such as sweet potato weevil. Weevils that survived in stems 
and roots will infest neighbouring sweet potato plants. To overcome this problem, crop residues in the field must be destroyed after harvest [52]. Traditionally, infested sweet potato fields were flooded to induce the rotting of leftover plant materials and to reduce the chances of weevil infestation in neighbouring plants. However, it was only in 1987 that experiment to study the effect of flooding of infested fields on the weevil densities in sweet potato plantation was conducted [47]. This was conducted by maintaining standing water over recently harvested weevil-infested sweet potato fields for approximately 4 weeks. The results showed that the number of insects (including larvae, pupae, and adults) per plant decreased over the flooding duration from 1 week to 4 weeks, demonstrating that flooding could be a safe and costeffective method to reduce weevils infestation in sweet potato plantation.

3.4. Entomopathogenic Nematodes. Biological control method using entomopathogenic nematodes has been found to have beneficial interaction with sweet potato and offers a promising way to suppress sweet potato weevil population. The entomopathogenic nematodes, Steinernematidae and Heterorhabditidae, have high reproductive potential and are safe to nontarget organisms, two characteristics which make them attractive for use against pests such as sweet potato weevils [53].

Infective juvenile entomopathogenic nematodes penetrate the body cavity of larvae via the mouth or breathing pores by using a tooth-like structure that pierce into the host soft intersegmental membranes [54]. Once inside, the nematodes start releasing pathogenic bacteria, Photorhabdus by Heterorhabditidae and Xenorhabdus by Steinernematidae, into the larvae body cavity, where the bacteria will reproduce rapidly and cause larvae death within two days $[55,56]$. Mutualistic relationship exists between the bacteria and nematodes in which the bacteria supply nutrients to the nematodes by killing the insect host, while the nematodes provide shelter to the bacteria [57].

The use of entomopathogenic nematodes in controlling sweet potato weevils offers several advantages: they are environmentally safe, infective juveniles can be used together with most pesticides $[58,59]$, and they are host-specific [60]. Jansson et al. [61] conducted an experiment to test the effect of entomopathogenic nematodes on C. formicarius and the results showed that the application of entomopathogenic nematodes (Heterorhabditidae bacteriophora) consistently reduces damages to sweet potato roots and is thus suitable to control weevil infestation.

3.5. Entomopathogenic Fungi. Entomopathogenic fungi are by far one of the most effective biological control agents of sweet potato weevil due to their host-specificity. Entomopathogenic fungi are one of the first organisms involved in biological control of pests and recently more than 700 species are found to be pathogenic to insects [62]. These fungi infect their hosts by entry into the host, followed by evasion of host defence reactions and multiplication and finally exit from the host [63]. The physicochemical features of disease development require interaction of entomopathogenic fungi with the insect host's outer tissues before producing toxic metabolites to evade or interact with the insect's defense mechanisms, though some metabolites were found lacking this ability [64, 65].

Several mechanisms are used by entomopathogenic fungi to evade the insect host defense system within the hemolymph, including changes in outer cellular layer of the fungi and the production of immunomodulating substances to suppress host defense system $[66,67]$. Entomopathogenic fungi produce a relatively high level of toxic metabolites, enabling them to tolerate the insect's immunological defense system. For instance, Beauveria bassiana produces $10 \mathrm{kDa}$ of a proteinaceous metabolite to kill the larvae at metamorphosis stage by disrupting the granulocytes [68]. The death of the insect host usually is a result from depletion of nutrient resources, mechanical damage, and toxicosis [62].

Protein contributes $70 \%$ of the cuticle layer; thus proteases secreted by entomopathogenic fungi play an important role in digesting protein and penetrating the cuticle layer $[69,70]$. The cuticle degradation by proteases starts with the absorption of enzyme onto the cuticle by nonspecific electrostatic bonds, followed by protease active site contact with specific peptide sequences (on the cuticle) and lastly the hydrolysis of amino acids or peptide fragments of the cuticular protein. Besides, entomopathogenic fungi also secrete lipoxygenases, phospholipases, and lipases in order to degrade the host epicuticle which contains fats, lipoprotein, and waxy layers [71]. These three enzymes hydrolyze ester linkages in glycerophospholipids of host cuticle and result in cell lysis, destabilization of membranes, and release of second messengers [72].

Numerous studies and laboratory experiments have proven that entomopathogenic fungi are useful in the control of sweet potato weevil. Reddy et al. [73] conducted a field study to compare the effectiveness of entomopathogenic fungi, insecticides, and combination of both entomopathogenic fungi and insecticide in controlling sweet potato weevil by determining the adult weevils' mortality. Results showed that Metarhizium brunneum with spinosad (insecticide) and Beauveria bassiana with spinosad caused $100 \%$ adult weevil mortality at 48 hours after treatment, while Metarhizium brunneum and Beauveria bassiana alone required 168 to 192 hours after treatment to cause $100 \%$ mortality. Beside that, Ondiaka et al. [74] conducted an experiment to determine the effect of Beauveria bassiana and Metarhizium anisopliae on adult Cylas puncticollis and fecundity and viability of female Cylas puncticollis eggs. The results showed that spraying of Beauveria bassiana or Metarhizium anisopliae caused adult mortality between $62.5 \%$ and $89.2 \%$. In addition, adult females treated with both fungal species laid less eggs compared to control, suggesting that the fungi can reduce fecundity and egg viability significantly.

3.6. Bacterial Insect Pathogens. Bacteria insect pathogen can grow, multiply, and develop within an insect host, causing considerable damage to the host. Bacteria enter insect host through the oral cavity or outer integument, which consists of cuticle and epidermis. Bacteria need to overcome several threats after they have entered the insect host via the oral 
cavity, and these include high concentration of hydrogen ion and antibacterial substances in plant (insect food) and low oxidation-reduction potential in gut, which restrict the proliferation of bacteria. The bacteria establish themselves by penetrating epithelial cells of the gut and invading host hemocoel, which will eventually reduce the nutrients in the host gut, causing starvation or sickness to the host [75].

Biocontrol agents are generally divided into three main groups: Group 1-agents will recycle naturally to exert permanent effect of pest control once they are introduced into the pest population; Group 2-agents disappear quickly from the pest population and they must be reapplied regularly; and Group 3-agents can behave like Group 1 or Group 2 based on the combination of pest species, environment, and agent strains. Among the most commonly used bacteria in pest management, industrially produced Bacillus popilliae falls into Group 1, which has long-term economic control on pests. On the other hand, industrially produced Bacillus thuringiensis falls into Group 2, which has practical but transient control of pests, and lastly Bacillus sphaericus falls into Group 3, which has mixed characteristics of Groups 1 and 2 [76].

Group 1 bacteria produce spores near the soil surface. Larvae, which feed on the roots below soil surface, will eventually consume the bacterial spores that have contaminated their food. The rate of disease development depends on temperature, spore size, and spore dosage. Long-term parasite-host balance can be ensured due to the absence of toxins, involvement of vernalization, and the complexity of Group 1 bacterial spores [77]. Group 2 bacteria produce crystal toxin, which attacks host gut wall, impairing enzyme secretion and lowering the $\mathrm{pH}$ of the gut so that the spores could germinate [78]. The multiplication of Group 2 bacteria in the host gut results in mouth paralysis, septicaemia, starvation, larvae death, reduced egg production, infertility, and bacteria sporulation. However, the application of Group 2 bacteria as outdoor microbial insecticide possesses several disadvantages such as the inability to spread widely among pest populations, rapid disappearance, and being easily destroyed by solar radiation [79]. On the other hand, partial digestion of Group 3 bacteria will release toxin after ingestion of spores and the toxin will penetrate into the peritrophic membrane before expressing its toxicity. Group 3 bacteria will usually multiply rapidly, sporulate, and infect healthy larvae after the disintegration of cadaver [80].

The application of bacteria in controlling pests offers several advantages including long shelf life of bacterial spores, high resistance to unfavourable environment, and small size that permits effortless design as chemical pesticides. Furthermore, bacteria are safe to nontarget organisms including beneficial flora and fauna, have low production cost, and do not require safety precautions during their application [75].

3.7. Sterile Insect Technique. Irradiation of sweet potato weevil with gamma rays is known as sterile insect technique (SIT). It is frequently used for the sterilization of weevil in tubers meant for long storage or export purposes [81, 82] and for the release of irradiated weevils into environment for eradication programmes [83].
The sterile males will vastly outnumber wild males and compete for the females in mating. The mating of sterile males with females will not produce offspring, resulting in a dramatic reduction in the next generation population [84]. Other than affecting fertility, the increase in absorption of radiation also causes negative effects on somatic cells and reduces the insect quality [85]. For instance, radiation damages the midgut epithelium, which disrupts the insect's nourishment process [86].

Setokuchi et al. [87] conducted a long-term experiment to investigate the efficiency of sterile insect release method to eradicate Cylas formicarius in the field. They irradiated weevils with $80 \mathrm{~Gy}$, stained them with fluorescent dyes, and released them in a release zone in 1994 and 1995. The weevils were monitored using pheromone traps and root traps (1994 to 1995) and the effect of sterile weevil release was reexamined in 1996. The results showed that the number of unmarked weevils caught in the release zone was reduced to nearly zero in 1995 and no living weevils were captured in both pheromone and root traps during the reexamination in the release zone in 1996. This showed that sterile insect release method is useful in controlling sweet potato weevil infestation.

More recently, Kumano and colleagues [83] have conducted experiments to determine the irradiation effect (200 Gy dose) on the mating ability in Cylas formicarius elegantulus male by comparing the longevity, mating performance, and mating competitiveness with the control male. The results showed that the survival of male weevils decreased drastically after being irradiated with gamma rays. Beside $C$. formicarius, SIT has also been used to target E. postfasciatus (West Indian sweet potato) but due to the lack of effective attractant, the dispersal activity of this pest is currently limited [46].

To sum up, sterile insect technique is a viable method to reduce weevil population in sweet potato plantation. However, the effect of their release into the environment in the long term, ecosystem consequences, effects on ecological needs, and potential of resistance should be well studied before this method can be widely practised [88].

3.8. Chemical Control. Various synthetic chemical insecticides are currently used in sweet potato plantation to prevent or treat sweet potato weevil infestation. Organophosphates chlorpyriphos and imidacloprid, which are chloronicotinyl insecticides, act primarily on the insect central nervous system by binding irreversibly to insect nicotinic receptor, leading to nicotinergic neuronal pathway obstruction and eventually failure in production of acetylcholinesterases. Acetylcholinesterases are required to break down or deactivate acetylcholine in chemical synapse. The lack of this enzyme will result in accumulation of acetylcholine, overstimulation of cholinergic synapses, paralysis, and eventually the death of the insect [89].

Mason and Jansson [90] conducted an experiment to compare the toxicity of five insecticides: parathion, carbamate methomyl, chlorpyrifos, chlorinated hydrocarbon endosulfan, and carbamate carbaryl, against adult Cylas formicarius using Petri dish bioassays in laboratory. The results showed 
that organophosphates parathion and chlorpyrifos were the most toxic as they had the lowest $\mathrm{LD}_{50}$ values (1.97 and $5.12 \mu \mathrm{g} / \mathrm{g}$ of wet biomass), followed by methomyl $(6.03 \mu \mathrm{g} / \mathrm{g}$ of wet biomass), endosulfan (57.44 $\mu \mathrm{g} / \mathrm{g}$ of wet biomass), and lastly carbaryl $(297.41 \mu \mathrm{g} / \mathrm{g}$ of wet biomass). Due to their higher toxicity, chlorpyrifos and parathion were suggested for the control of sweet potato weevils. In a separate study, Hwang and Hung [91] conducted a field experiment to test the efficacy of five insecticides: chlorpyrifos, phorate, terbufos, fensulfothion, and carbofuran, in controlling sweet potato weevils, by applying the insecticide twice to soil before planting and during earthing up. The results showed that chlorpyrifos had the highest rate of control $(76.8 \%)$, followed by fensulfothion (51.3\%), phorate (44.9\%), carbofuran $(38.8 \%)$, and lastly terbufos $(38.0 \%)$. In both studies, chlopryrifos demonstrated a high efficacy in suppressing sweet potato weevil infestation and hence it is widely used in the integrated pest management of this pest.

3.9. Sex Pheromone Trap. Sex pheromone trap is widely used to capture adult sweet potato weevil in plantation owing to its high efficiency [92]. The trap is usually designed with synthetic pheromone lure such as (Z)-3-dodecen-1-ol (E)-2butenoate together with ethyl acetate and is usually placed at ground level to facilitate the entrance of adult weevils, which will then be killed by the insecticide inside the trap. Pheromones are used in three ways: mass trapping to reduce insect pest population, insect populations monitoring using pheromone traps, and mating disruption by applying high dosage of pheromone in the atmosphere [92].

(Z)-3-Dodecen-1-ol (E)-2-butenoate, isolated from female sweet potato weevils and synthesized chemically [93], is a successful mating disruptant of sweet potato weevils [94]. This novel compound provides several economic applications such as the detection of weevil outbreaks, the monitoring of an existing weevil population to schedule eradication programmes, and the control of mating in adult populations by attracting a large portion of male weevils or by disruption of mating through inhibitory properties [94].

Reddy et al. [95] conducted a field study in Guam to determine the efficacy of controlling Cylas formicarius using bucket traps with (Z)-3-dodecen-1-ol (E)-2-butenoate. Their effectiveness was measured by the total damages caused by weevil and the total sweet potato yield for that season. The results showed that sweet potato roots damage in both locations with traps was very low ( $<$ one feeding hole per root) from June to September, compared to locations without traps (approximately 38 feeding holes per root) during the same duration. The sweet potato yield in fields with traps was higher (13.47 tonnes per hectare at Inarajan and 14.59 tonnes per hectare at Yigo) compared to fields without traps (7.86 tonnes per hectare at Ija and 8.26 tonnes per hectare at Dededo), proving that pheromone traps are effective in reducing the damage done by sweet potato weevil due. Reddy et al. [96] also conducted a study to evaluate four parameters (size, trap colour, trap design, and height of traps placement) that influence the effectiveness of sex pheromone trap used together with (Z)-3-dodecen-1-ol (E)-2-butenoate. The result showed that medium-sized red Pherocon (USA) unitraps
$(13 \mathrm{~cm} \times 17.5 \mathrm{~cm})$ were more effective to increase the efficacy of sex pheromone traps for sweet potato weevils.

In a separate study, Smit and colleagues [97] conducted field experiments to determine the efficacy of mass trapping of C. brunneus and C. puncticollis by using decyl (E)-2butenoate and dodecyl (E)-2-butenoate, one of the important components of adult sweet potato female weevil sex pheromones. The traps, baited with $0.1 \mathrm{mg}$ of decyl (E)2-butenoate and dodecyl (E)-2-butenoate, were placed in 0.5 -hectare fields. Four trials with durations ranging from 31 to 37 weeks were carried out. The results showed that a maximum reduction in the population of male Cylas brunneus and Cylas puncticollis (89\%) was achieved from the four trials. This proved that pheromone traps baited with female sex pheromone could reduce the male sweet potato weevil population effectively and ultimately reduce the chances of mating in the population.

\section{The Future of Sweet Potato Crop}

Advancements in molecular biology tools including Next Generation Sequencing have provided multiple advantages in the understanding and study of economically important crops. Currently, the International Potato Center (CIP), the main research organization working on root crops, is collaborating with the University of Ghent to determine the sequence the whole genome of Ipomoea batatas cv. Huachano using SOLiD complete genome shotgun sequencing. The lack of whole genome sequencing data of sweet potato has hindered DNA fingerprinting, development of molecular markers, and genetic analyses of this crop. DNA fingerprinting is important in many crop species for the identification of crops to protect the rights of plant breeders. Monden et al. [98] had conducted DNA fingerprinting based on the two active retrotransposon families (Line-type LIb and LTR-type Rtsp-1) in sweet potato, which exhibited high insertion polymorphisms, by using the MiSeq sequencing platform. The polymorphism of these insertion sites was very high (91.4\%) and the insertion sites, which are cultivar-specific, were successfully converted into amplified region markers. The markers helped in the precise identification of sweet potato cultivars.

Tao et al. [99] conducted a transcriptomic study on sweet potato to further understand the molecular mechanism and gene expression in different tissues at different developmental stages as well as the biotic and abiotic stress responses in sweet potato. From this study, a large number of genes were found responding to drought, salt, heat, and osmotic stress such as those encoding metallothionein (MT), aquaporin (AQP), and abscisic acid responsive elements binding factor (AREB). Understanding the expression patterns of these genes could possibly lead to a stronger crop in the near future. Prior to this, two other sweet potato transcriptomes were sequenced by the International Potato Center and the Guangdong Academy of Agricultural Sciences of China using the Roche-454 pyrosequencing technology [100] and the Illumina/Solexa RNA-Seq technology [101], respectively. These studies have led to new paths in collating differentially expressed genes in the different tissues at the different development stages. This will also allow better understanding 
of the different genes involved in the pathways and provides information for further modification in gene expression to improve the quality of the crops.

Aside from this, development of orange-fleshed sweet potato with high level of beta-carotene is seen as a strategy to improve the nutritional status of millions of children in developing or underdeveloped countries. However, conventional breeding of orange-fleshed sweet potatoes are difficult due to their genetic complexity, thus marker-assisted breeding tools must be developed to assist in their breeding. A study was conducted to determine the quantitative trait loci (QTL) for starch, beta-carotene, and dry matter content in sweet potato [102]. The identification of QTL was based on the hexaploid sweet potato mapping population that resulted from a cross between Beauregard and Tanzania sweet potato cultivars in USA. QTL analysis in two parental maps [103] revealed 12 QTL for starch content, 8 QTL for beta-carotene, and 13 QTL for dry matter content in storage root. The results improve our understanding of these important traits in sweet potato, which are important for the development of marker-assisted breeding tools to increase sweet potato breeding efficiency.

The development of transgenic sweet potato with foreign genes that confer additional properties such as insect resistance is important to reduce economic losses due to pest infestation. The progress of breeding sweet potato with weevil resistance is slow due to scarcity of sweet potato varieties that display significant resistance levels [104], hindering progress in this area. Most of the early works focused on the transformation of sweet potato with proteins that decrease sweet potato digestibility for insects. Newell et al. [105] transformed sweet potato with mannose binding snowdrop lectin and cowpea trypsin inhibitor. Both transgenic sweet potatoes showed a moderate increase in resistance of sweet potato weevil. In a separate work, Cipriani et al. [106, 107] transformed soybean Kunitz type trypsin inhibitor and rice cysteine proteinase inhibitor into sweet potato. However, the transformation works, which focused on proteinase inhibitors, were abandoned due to concerns regarding nutritional impact of the proteins on human diet and after observing a small increase in weevil resistance against the proteinase inhibitors [108].

A number of studies have supported the high efficiency usage of Bacillus thuringiensis in controlling different pests including sweet potato weevils. García et al. [109] transformed the stems and leaves of sweet potato with Agrobacterium tumefaciens carrying nptII and Bacillus thuringiensis $\mathrm{Bt}$ endotoxin gene. The plants were then tested for resistance against sweet potato weevil under controlled conditions. Their results showed that the transgenic sweet potato carrying Bt gene had higher resistance compared to control plants (weevil damage on the normal sweet potato was five times higher compared to transgenic). The transformation of crops with Bacillus thuringiensis Cry proteins showed promising results in pest control through the expression of insecticidal compounds. Morán et al. [110] conducted a study to transform Cry3A gene into sweet potato roots to fend against sweet potato weevil, Cylas formicarius. The transformed sweet potatoes were able to express Cry $3 \mathrm{~A}$ protein but this research was discontinued, as the control of Cylas formicarius with
Cry3A was not promising. Ekobu et al. [111] conducted an experiment to evaluate the toxicity of Cry proteins to Cylas puncticollis and Cylas brunneus. They showed that three Cry proteins: ET33/34, Cry7Aal, and Cry3Cal had $\mathrm{LC}_{50}$ below $1 \mu \mathrm{g} / \mathrm{gram}$ diet, thereby proved that these transformed sweet potatoes can be used against weevil infestation.

Other biotechnological approaches have also shown promising results on pest control, including introduction of small RNA viruses that interfere with weevil life cycle [112], spider venom toxins [113], and RNA-mediated interference [114]. RNA-mediated interference promotes posttranscriptional gene silencing and has been used in insect management and virus disease resistance development in sweet potato. For example, Kreuze et al. [115] conducted an experiment to develop sweet potato with RNA silencing-mediated resistance to sweet potato chlorotic stunt virus. They found that $50 \%$ of the tested transgenic events showed mild or no symptoms of infection of the virus and the accumulation of the virus in the transgenic sweet potato was significantly reduced.

In all, the understanding of the biology of sweet potato weevil infestation is essential so that specific preventive method can be designed. Numerous strategies and techniques have been used in the different regions; however, until recently, they only serve to suppress the potential damages by the weevils without addressing the underlying problem. The momentum in biotechnology research field has given the sweet potato industry a promising future. Despite the absence of transgenic weevil resistance sweet potato in the market, hopefully, the various research teams currently working on this can release the long-awaited transgenic sweet potato to consumers soon.

\section{Conflict of Interests}

The authors declare that there is no conflict of interests regarding the publication of this paper.

\section{References}

[1] Food and Agriculture Organization of the United Nations (FAO), Food and Agriculture Organization Statistical Databases (FAOSTAT), 2015, http://faostat3.fao.org/browse/Q/QC/E.

[2] A. Elameen, S. Fjellheim, A. Larsen et al., "Analysis of genetic diversity in a sweet potato (Ipomoea batatas L.) germplasm collection from Tanzania as revealed by AFLP," Genetic Resources and Crop Evolution, vol. 55, no. 3, pp. 397-408, 2008.

[3] L. E. Jackai, B. Sosinski, D. M. Jackson et al., "Occurrence and intra-specific variation of sweetpotato weevil (Brentidae: Coleoptera) in relation to its potential spread in southern United States of America and the Caribbean," in ISHS Acta Horticulturae 703: II International Symposium on Sweetpotato and Cassava: Innovative Technologies for Commercialization, pp. 197-204, International Society for Horticultural Science, Leuven, Belgium, 2006.

[4] R. B. Chalfant, R. K. Jansson, D. R. Seal, and J. M. Schalk, "Ecology and management of sweet potato insects," Annual Review of Entomology, vol. 35, no. 1, pp. 157-180, 1990.

[5] R. R. Korada, S. K. Naskar, M. S. Palaniswami, and R. C. Ray, "Management of sweetpotato weevil [Cylas formicarius (Fab.)]: an overview," Journal of Root Crops, vol. 36, pp. 14-26, 2000. 
[6] T. Ames, N. E. J. M. Smit, A. R. Braun, J. N. O'Sullivan, and L. G. Skoglund, Sweetpotato: Major Pests, Diseases, and Nutritional Disorders, International Potato Center (CIP), Lima, Peru, 1996.

[7] Taiwan Agricultural Chemicals and Toxic Substances Research Institute Council of Agriculture (TACTRI/COA), Sweetpotato Healthy Management Technique and Operation Manual, 2014, http://ir.tari.gov.tw:8080/bitstream/345210000/5366/2/no163 .pdf.

[8] Anonymous, Insect Pests of Sweetpotato, Shanghai Science Press, Shanghai, China, 1984.

[9] N. V. Dinh, H. L. Khang, N. V. The et al., Preliminary Results of IPM Application to Sweetpotato in Thanh Binh, Agricultural Publishing House, Hanoi, Vietnam, 1995.

[10] A. H. Bahagiawati, Bionomics and Control of the Sweetpotato Weevil, Cylas Formicarius in Indonesia, Bogor Research Institute for food crops, Bogor, Indonesia, 1989.

[11] A. R. Braun and E. van de Fliert, "Evaluation of the impact of sweetpotato weevil (Cylas formicarius) and of the effectiveness of Cylas sex pheromone traps at the farm level in Indonesia," International Journal of Pest Management, vol. 45, no. 2, pp. 101110, 1999.

[12] T. H. Ho, "Studies on some major pests of sweetpotatoes and their control," The Malaysian Agricultural Journal, vol. 47, no. 4, pp. 437-452, 1970.

[13] R. M. Gapasin, "Studies on the major diseases and insect pests of sweetpotato at VISCA, the Philippines," in Weetpotato Research and Development for Small Farmers, K. T. Mackay, M. K. Palomar, and R. T. Sanico, Eds., pp. 151-168, SEAMEOSEARCA College, Laguna, Philippines, 1989.

[14] T. Suenaga, O. Setokuchi, and K. Sakae, "Distribution of the sweetpotato weevil Cylas formicarius Fabricius and the small sweetpotato weevil, Euscepes postfasciatus Fairmaire in the Amami Islands," Kyushu Plant Protection Research, vol. 33, pp. 116-118, 1987.

[15] N. E. J. M. Smit, "The effect of the indigenous cultural practices of in-ground storage and piecemeal harvesting of sweetpotato on yield and quality losses caused by sweetpotato weevil in Uganda," Agriculture, Ecosystems and Environment, vol. 64, no. 3, pp. 191-200, 1997.

[16] R. Kapinga, K. Mtunda, D. Chillosa, and D. Rees, "An assessment of damage of traded fresh sweetpotato roots," in Roots and Tuber Crops Research Programme, Progress Report for 1996, Mwanza, Ed., Research and Training Department, Ministry of Agriculture and Co-Operatives, Dar es Salaam, Tanzania, 1997.

[17] K. O. Fuglie, "Priorities for sweetpotato research in developing countries: results of a survey," HortScience, vol. 42, no. 5, pp. 1200-1206, 2007.

[18] J. Nderitu, M. Silai, G. Nyamasyo, and M. Kasina, "Insect species associated with sweet potatoes (Ipomoea batatas (L.) Lam) in Eastern Kenya," International Journal of Sustainable Crop Production, vol. 4, no. 1, pp. 14-18, 2009.

[19] United States Environmental Protection Agency (USEPA), Strategic Plan for Pest Management Research \& Education in Southern Sweetpotato Production Systems, United States Environmental Protection Agency (USEPA), 2003, http://www .ipmcenters.org/pmsp/pdf/sesweetpotato.pdf.

[20] R. K. Jansson, H. H. Bryan, and K. A. Sorensen, "Within-vine distribution and damage of sweetpotato weevil, Cylas formicarius elegantulus (Coleoptera: Curculionidae), on four cultivars of sweetpotato in southern Florida," The Florida Entomologist, vol. 70, no. 4, pp. 523-526, 1987.
[21] D. N. Maynard, G. J. Hochmuth, M. L. Lamberts et al., Sweetpotato Production in Florida, 1999, http://university.uog.edu/ cals/people/PUBS/Sweetpot/CV13600.pdf.

[22] A. Swindale, Measurement of the Economic Importance of Sweetpotato Weevil, International Potato Center, Lima, Peru, 1992.

[23] J. Alcazar, F. Cisneros, and A. Morales, "Large-scale implementation of IPM for sweetpotato weevil in Cuba: a collaborative effort," Working Paper (CIP), 1997.

[24] J. L. Capinera, Handbook of Vegetable Pests, Academic Press, San Diego, Calif, USA, 2001.

[25] I. C. Onwueme and W. B. Charles, "Tropical root and tuber crops: production, perspectives and future prospects," FAO Plant Prod Prot Paper 126:129, Food and Agriculture Organization of the United Nations, Rome, Italy, 1994.

[26] I. Uritaini, T. Saito, H. Honda, and W. K. Kim, "Induction of furanoterpenoids in sweetpotato roots by the larval components of the sweetpotato weevils," Agricultural and Biological Chemistry, vol. 37, pp. 1875-1862, 1975.

[27] R. K. Rao, "Systems approach for management of insect pest problem in tuber crops by farmers of Meghalaya," CTCRI News, vol. 22, pp. 3-4, 2005.

[28] V. S. Teli and G. N. Salunkhe, "A search for sources of resistance to sweet potato weevil. I. Morphological traits," Journal of Maharashtra Agricultural Universities, vol. 20, pp. 400-403, 1996.

[29] K. C. Son, R. F. Severson, R. F. Arrendale, and S. J. Kays, “Surface chemical differences between sweetpotato lines with varying levels of resistance to the sweetpotato weevil," Journal of the American Society for Horticultural Science, vol. 115, no. 4, pp. 696-699, 1990.

[30] S. F. Nottingham, K.-C. Son, D. D. Wilson, R. F. Severson, and S. J. Kays, "Feeding and oviposition preferences of sweet potato weevil, Cylas formicarius elegantulus (Summers), on storage roots of sweet potato cultivars with differing surface chemistries," Journal of Chemical Ecology, vol. 15, no. 3, pp. 895903, 1989.

[31] M. Lima and A. Morales, Estudios Comparativos de Clones Precoces de Boniato [Ph.D. thesis], University "Marta Abreu" of Las Villas, 1992.

[32] N. Smith and B. Odongo, Integrated Pest Management for Sweetpotato in East Africa, International Potato Center (CIP), Lima, Peru, 2002.

[33] Asian Vegetable Research and Development Center (AVRDC), AVRDC Progress Report Summaries 1990, Asian Vegetable Research and Development Center, Shanhua, Taiwan, 1990.

[34] T. Gomi, M. Nagasaka, T. Fukuda, and H. Higahara, "Shifting of the life cycle and life-history traits of the fall webworm in relation to climate change," Entomologia Experimentalis et Applicata, vol. 125, no. 2, pp. 179-184, 2007.

[35] M. Ladányi and L. Hufnagel, "The effect of climate change on the population of Sycamore lace bug (Corythuca ciliata, say, tingidae heteroptera) based on a simulation model with phenological response," Applied Ecology and Environmental Research, vol. 4, no. 2, pp. 85-112, 2006.

[36] P. Rajamma, "Biology and bionomics of sweetpotato weevil, Cylas formicarius Fabr," in Proceedings of the Symposium on Insect Ecology and Resource Management, S. D. Goel, Ed., pp. 87-92, Sanatan Dharm College, Muzaffarnagar, India, 1983.

[37] J. S. Okonya and J. Kroschel, "Incidence, abundance and damage by the sweet potato butterfly (Acraea acerata Hew. and the 
African sweet potato weevils (Cylas spp.) across an altitude gradient in Kabale district, Uganda," International Journal of AgriScience, vol. 3, no. 11, pp. 814-824, 2013.

[38] P. S. Bhat, Tropical Tuber Crops: Problems, Prospects and Future Strategies, Science Publishers, Chennai, India, 1996.

[39] S. K. Hahn and K. Leuschner, "Breeding of sweetpotato for weevil resistance," in Proceedings of the 1st International Symposium on Sweetpotato, R. L. Villareal and T. D. Griggs, Eds., pp. 331-336, Asian Vegetable Research and Development Center, Shanhua, Taiwan, 1982.

[40] P. Rajamma and G. Padmaja, Annual Report, Central Tuber Crops Research Institute, Trivandrum, India, 1981.

[41] J. A. Sutherland, "Damage by Cylas formicarius Fab. to sweetpotato vines and tubers, and the effect of infestations on total yield in Papua New Guinea," Tropical Pest Management, vol. 32, no. 4, pp. 316-323, 1986.

[42] K. S. Pillai, P. Rajamma, and C. S. Ravindran, "Effect of crop rotation on the incidence of sweetpotato weevil," in Annual Progress Report 1986 for the Period January-December 1986, pp. 47-49, Central Tuber Crops Research Institute, Kerala, India, 1987.

[43] K. S. Pillai, M. S. Palaniswami, P. Rajamma, C. S. Ravindran, and T. Premkumar, "An IPM approach for sweetpotato weevil," in Tropical Tuber Crops: Problems, Prospects and Future Strategies, G. T. Kurup, M. S. Palaniswami, V. P. Potty, G. Padmaja, Kabeerathumma, and S. V. Pillai, Eds., pp. 329-339, Science Publishers, Chennai, India, 1996.

[44] P. Alcarez, V. Escarramán, E. Gómez et al., "Economic impact of managing sweetpotato weevil (Cylas formicarius) with sex pheromones in the Dominican Republic," in Case Studies of the Economic Impact of CIP Related Technology, T. S. Walker and C. C. Crissman, Eds., pp. 83-94, International Potato Center, Lima, Peru, 1996.

[45] H. J. Reinhard, "The sweet potato weevil," Texas Agricultural Experiment Station Bulletin, vol. 308, pp. 7-90, 1923.

[46] S. Moriya and T. Miyatake, "Eradication programs of two sweetpotato pests, Cylas formicarius and Euscepes postfasciatus, in Japan with special reference to their dispersal ability," Japan Agricultural Research Quarterly, vol. 35, no. 4, pp. 227-234, 2001.

[47] K. Komi, "Eradication of sweetpotato weevil, Cylas Formicarius Fabricius from Muroto City, Kochi, Japan," in Extension Bulletin-Food Fertilizer Technology Center, vol. 493, pp. 15-22, Food and Fertilizer Technology Center, 2000.

[48] N. S. Talekar, "Influence of cultural pest management techniques on the infestation of sweetpotato weevil," International Journal of Tropical Insect Science, vol. 8, pp. 809-814, 1987.

[49] M. S. Palaniswami and N. Mohandas, "Reridging as a cultural method for the management of sweetpotato weevil Cylas formicarius F.," Journal of Root Crops, vol. 20, pp. 101-105, 1994.

[50] F. Cisneros and P. Gregory, "Potato pest management," Aspects of Applied Biology, vol. 39, pp. 113-124, 1994.

[51] F. Cisneros, J. Alcazar, M. Palacios, and O. Ortiz, "A strategy for developing and implementing integrated pest management," CIP Circular, vol. 21, no. 3, pp. 2-7, 1995.

[52] R. K. Jansson, R. R. Heath, and J. A. Coffelt, "Temporal and spatial patterns of sweetpotato weevil (Coleoptera: Curculionidae) counts in pheromone-baited traps in white-fleshed sweet potato fields in southern Florida," Environmental Entomology, vol. 18, no. 4, pp. 691-697, 1989.

[53] H. K. Kaya and R. Gaugler, "Entomopathogenic nematodes," Annual Review of Entomology, vol. 38, no. 1, pp. 181-206, 1993.
[54] R. A. Bedding and A. S. Molyneux, "Penetration of insect cuticle by infective juveniles of Heterorhabditis spp. (Heterorhabditidae: Nematoda)," Nematologica, vol. 28, no. 3, pp. 354-359, 1982.

[55] B. J. Adams and K. B. Nguyen, "Taxonomy and systematic," in Entomopathogenic Nematology, vol. 1, CABI, Wallingford, UK, 2002.

[56] G. O. Poinar Jr., "Biology and Taxonomy of Steinernematide and Heterorhabditidae," in Entomopathogenic Nematodes in Biological Control, R. Gaugler and H. K. Kaya, Eds., pp. 23-62, CRC Press, Boca Raton, Fla, USA, 1990.

[57] R. D. M. Page, "Parasites, phylogeny and cospeciation," International Journal for Parasitology, vol. 23, no. 4, pp. 499-506, 1993.

[58] B. T. Forschler, J. N. All, and W. A. Gardner, "Steinernema feltiae activity and infectivity in response to herbicide exposure in aqueous and soil environments," Journal of Invertebrate Pathology, vol. 55, no. 3, pp. 375-379, 1990.

[59] L. Rovesti and K. V. Deseö, "Compatibility of pesticides with the entomopathogenic nematode, heterorhabditis heliothidis," Nematologica, vol. 37, no. 1-4, pp. 113-116, 1991.

[60] J. F. Campbell, E. E. Lewis, S. P. Stock, S. Nadler, and H. K. Kaya, "Evolution of host search strategies in entomopathogenic nematodes," Journal of Nematology, vol. 35, no. 2, pp. 142-145, 2003.

[61] R. K. Jansson, S. H. Lecrone, and R. Gaugler, "Comparison of single and multiple releases of Heterorhabditis bacteriophora Poinar (Nematoda: Heterorhabditidae) for control of Cylas formicarius (Fabricius) (Coleoptera: Apionidae)," Biological Control, vol. 1, no. 4, pp. 320-328, 1991.

[62] R. Pinnamaneni and K. Potineni, "Mechanisms involved in the entomopathogenesis of Beauveria bassiana," Asian Journal of Environmental Science, vol. 5, no. 1, pp. 65-74, 2010.

[63] G. Xiao, S.-H. Ying, P. Zheng et al., "Genomic perspectives on the evolution of fungal entomopathogenicity in Beauveria bassiana," Scientific Reports, vol. 2, no. 483, pp. 1-10, 2012.

[64] M. J. Bidochka and G. G. Khachatourians, "The implication of metabolic acids produced by Beauveria bassiana in pathogenesis of the migratory grasshopper, Melanoplus sanguinipes," Journal of Invertebrate Pathology, vol. 58, no. 1, pp. 106-117, 1991.

[65] B. H. Kirkland, A. Eisa, and N. O. Keyhani, "Oxalic acid as a fungal acaracidal virulence factor," Journal of Medical Entomology, vol. 42, no. 3, pp. 346-351, 2005.

[66] J. C. Pendland and D. G. Boucias, "Ultrastructural localization of carbohydrate in cell walls of the entomogenous hyphomycete Nomuraea rileyi," Canadian Journal of Microbiology, vol. 38, no. 5, pp. 377-386, 1992.

[67] J. C. Pendland, S.-Y. Hung, and D. G. Boucias, "Evasion of host defense by in vivo-produced protoplast-like cells of the insect mycopathogen Beauveria bassiana," Journal of Bacteriology, vol. 175, no. 18, pp. 5962-5969, 1993.

[68] I. Mazet, S.-Y. Hung, and D. G. Boucias, "Detection of toxic metabolites in the hemolymph of Beauveria bassiana infected Spodoptera exigua larvae," Experientia, vol. 50, no. 2, pp. 142147, 1994.

[69] R. H. Hackmann, "Cuticle: biochemistry," in Biology of the Integument: Invertebrates, J. Bereiter-Hahn, A. G. Matoltsy, and K. S. Richards, Eds., pp. 583-610, Springer, Berlin, Germany, 1984.

[70] A. C. Neville, "Cuticle: organisation," in Biology of the Integument: Invertebrates, J. Bereiter-Hahn, A. G. Matoltsy, and K. S. Richards, Eds., pp. 611-625, Springer, Heidelberg, Germany, 1984. 
[71] M. J. Bidochka and G. G. Khachatourians, "Growth of the entomopathogenic fungus Beauveria bassiana on cuticular components from the migratory grasshopper, Melanoplus sanguinipes," Journal of Invertebrate Pathology, vol. 59, no. 2, pp. 165-173, 1992.

[72] M. A. Ghannoum, "Potential role of phospholipases in virulence and fungal pathogenesis," Clinical Microbiology Reviews, vol. 13, no. 1, pp. 122-143, 2000.

[73] G. V. P. Reddy, Z. H. Zhao, and R. A. Humber, "Laboratory and field efficacy of entomopathogenic fungi for the management of the sweetpotato weevil, Cylas formicarius (Coleoptera:Brentidae)," Journal of Invertebrate Pathology, vol. 122, pp. 10-15, 2014.

[74] S. Ondiaka, N. K. Maniania, G. H. N. Nyamasyo, and J. H. Nderitu, "Virulence of the entomopathogenic fungi Beauveria bassiana and Metarhizium anisopliae to sweet potato weevil Cylas puncticollis and effects on fecundity and egg viability," Annals of Applied Biology, vol. 153, no. 1, pp. 41-48, 2008.

[75] A. M. Heimpel and J. C. Harshbarger, "Symposium on microbial insecticides. V. Immunity in insects," Bacteriological Reviews, vol. 29, no. 3, pp. 397-405, 1965.

[76] H. D. Burges, "Control of insects by bacteria," Parasitology, vol. 84, no. 4, pp. 79-117, 1982.

[77] B. Hurpin, "Microbial control of pest and plant diseases 19701980," Entomophaga, vol. 27, no. 1, article 115, 1982.

[78] K. E. Cooksey, "The protein crystal toxin of Bacillus thuringiensis biochemistry and mode of action," in Microbial Control of Insects and Mites, H. D. Burges and N. W. Hussey, Eds., pp. 247274, Academic Press, San Diego, Calif, USA, 1971.

[79] H. D. Burges, S. Hillyer, and D. O. Chanter, "Effect of ultraviolet and gamma rays on the activity of $\delta$-endotoxin protein crystals of Bacillus thuringiensis," Journal of Invertebrate Pathology, vol. 25, no. 1, pp. 5-9, 1975.

[80] E. W. Davidson and P. Myers, "Parasporal inclusions in Bacillus sphaericus," FEMS Microbiology Letters, vol. 10, no. 3, pp. 261265, 1981.

[81] P. A. Follett, "Irradiation as a methyl bromide alternative for postharvest control of Omphisa anastomosalis (Lepidoptera: Pyralidae) and Euscepes postfasciatus and Cylas formicarius elegantulus (Coleoptera: Curculionidae) in sweet potatoes," Journal of Economic Entomology, vol. 99, no. 1, pp. 32-37, 2006.

[82] G. J. Hallman, "Irradiation quarantine treatment research against arthropods other than fruit flies," IAEA-TECDOC 1427, IAEA, 2004.

[83] N. Kumano, D. Haraguchi, and T. Kohama, "Effect of irradiation on mating ability in the male sweetpotato weevil (Coleoptera: Curculionidae)," Journal of Economic Entomology, vol. 101, no. 4, pp. 1198-1203, 2008.

[84] N. Kumano, T. Kuriwada, K. Shiromoto, D. Haraguchi, and T. Kohama, "Prolongation of the effective copulation period by fractionated-dose irradiation in the sweet potato weevil, Cylas formicarius," Entomologia Experimentalis et Applicata, vol. 141, no. 2, pp. 129-137, 2011.

[85] C. O. Calkins and A. G. Parker, "Sterile insect quality," in Sterile Insect Technique: Principles and Practice in Area-Wide Integrated Pest Management, V. A. Dyck, J. Hendrichs, and A. S. Robinson, Eds., pp. 269-296, Springer, Dordrecht, The Netherlands, 2005.

[86] A. Bakri, K. Mehta, and D. Lance, "Sterilizing insects with ionizing radiation," in Sterile Insect Technique: Principles and Practice in Area-Wide Integrated Pest Management, V. A. Dyck, J. Hendrichs, and A. S. Robinson, Eds., pp. 233-268, Springer, Dordrecht, The Netherlands, 2005.
[87] O. Setokuchi, T. Sugimoto, T. Yamaguchi et al., "Efficiency of the sterile insect release method as an eradication measure for the sweet potato weevil, Cylas formicarius (Fabricius) (Coleoptera: Brentidae) in the field," Applied Entomology and Zoology, vol. 36, no. 1, pp. 161-167, 2001.

[88] L. Alphey, M. Benedict, R. Bellini et al., "Sterile-insect methods for control of mosquito-borne diseases: an analysis," VectorBorne and Zoonotic Diseases, vol. 10, no. 3, pp. 295-311, 2010.

[89] J. P. Giesy, K. R. Solomon, and K. A. Solomon, Ecological Risk Assessment for Chlorpyrifos in Terrestrial and Aquatic Systems in North America, Springer, New York, NY, USA, 2014.

[90] L. J. Mason and R. K. Jansson, "Disruption of sex pheromone communication in Cylas formicarius (Coleoptera: Apionidae) as a potential means of control," The Florida Entomologist, vol. 74, no. 3, pp. 469-472, 1991.

[91] J. S. Hwang and C. C. Hung, "Sweetpotato insect pest management and the application of sex pheromone," in Proceedings of the Symposium on Root Crop Yield Improvement, Processing and Utilization in Taiwan, pp. 229-245, TARI Special Publication, Chiayi, Taiwan, June 1994.

[92] A. F. Kydonieus and M. Beroza, Insect Suppression with Controlled Released Pheromone Systems, CRC Press, Boca Raton, Fla, USA, 1982.

[93] R. R. Heath, J. A. Coffelt, F. I. Proshold, P. E. Sonnet, and J. H. Tumlinson, "(Z)-3-dodecen-1-ol (E)-2-butenoate and its use in monitoring the sweetpotato weevil," US Patent 4732756, 1998.

[94] L. J. Mason, D. R. Seal, and R. K. Jansson, "Response of sweetpotato weevil (Coleoptera: Apionidae) to selected insecticides," The Florida Entomologist, vol. 74, no. 2, pp. 350-355, 1991.

[95] G. V. P. Reddy, S. H. Wu, R. C. Mendi, and R. H. Miller, "Efficacy of pheromone trapping of the sweetpotato weevil (Coleoptera: Brentidae): based on dose, septum age, attractive radius, and mass trapping," Environmental Entomology, vol. 43, no. 3, pp. 767-773, 2014.

[96] G. V. P. Reddy, N. Gadi, and A. J. Taianao, "Efficient sex pheromone trapping: catching the sweetpotato weevil, Cylas formicarius," Journal of Chemical Ecology, vol. 38, no. 7, pp. 846853, 2012.

[97] N. E. J. M. Smit, M. C. A. Downham, P. O. Laboke, D. R. Hall, and B. Odongo, "Mass-trapping male Cylas spp. with sex pheromones: a potential IPM component in sweetpotato production in Uganda," Crop Protection, vol. 20, no. 8, pp. 643-651, 2001.

[98] Y. Monden, A. Yamamoto, A. Shindo, and M. Tahara, "Efficient DNA fingerprinting based on the targeted sequencing of active retrotransposon insertion sites using a bench-top highthroughput sequencing platform," DNA Research, vol. 21, no. 5, pp. 491-498, 2014.

[99] X. Tao, Y.-H. Gu, H.-Y. Wang et al., "Digital gene expression analysis based on integrated de novo transcriptome assembly of sweet potato [Ipomoea batatas (L.) Lam.]," PLoS ONE, vol. 7, no. 4, Article ID e36234, 2012.

[100] R. Schafleitner, L. R. Tincopa, O. Palomino et al., "A sweetpotato gene index established by de novo assembly of pyrosequencing and Sanger sequences and mining for gene-based microsatellite markers," BMC Genomics, vol. 11, article 604, 2010.

[101] Z. Y. Wang, B. P. Fang, J. Y. Chen et al., "De novo assembly and characterization of root transcriptome using Illumina paired-end sequencing and development of cSSR markers in sweetpotato (Ipomoea batatas)," BMC Genomics, vol. 11, article 726, 2010. 
[102] J. C. Cervantes-Flores, B. Sosinski, K. V. Pecota et al., "Identification of quantitative trait loci for dry-matter, starch, and $\beta$ carotene content in sweetpotato," Molecular Breeding, vol. 28, no. 2, pp. 201-216, 2010 .

[103] J. C. Cervantes-Flores, G. C. Yencho, A. Kriegner et al., "Development of a genetic linkage map and identification of homologous linkage groups in sweetpotato using multiple-dose AFLP markers," Molecular Breeding, vol. 21, no. 4, pp. 511-532, 2008.

[104] P. C. Stevenson, H. Muyinza, D. R. Hall et al., "Chemical basis for resistance in sweetpotato Ipomoea batatas to the sweetpotato weevil Cylas puncticollis," Pure and Applied Chemistry, vol. 81, no. 1, pp. 141-151, 2009.

[105] C. A. Newell, J. M. Lowe, A. Merryweather, L. M. Rooke, and W. D. O. Hamilton, "Transformation of sweet potato (Ipomoea batatas (L.) Lam.) with Agrobacterium tumefaciens and regeneration of plants expressing cowpea trypsin inhibitor and snowdrop lectin," Plant Science, vol. 107, no. 2, pp. 215-227, 1995.

[106] G. Cipriani, D. Michaud, F. Brunelle, A. Golmirzaieand, and D. P. Zhang, "Expression of soybean proteinase inhibitor in sweetpotato," in CIP Program Report 1997-1998, pp. 271-277, International Potato Center, Lima, Peru, 1999.

[107] G. Cipriani, S. Fuentes, V. Bello, L. F. Salazar, M. Ghislain, and D. P. Zhang, "Transgene expression of rice cysteine proteinase inhibitors for the development of resistance against sweetpotato feathery mottle virus," in CIP Program Report 1999-2000, pp. 267-271, International Potato Center, Lima, Peru, 2001.

[108] R. O. M. Mwanga, M. Ghislain, J. Kreuze, G. N. Ssemakula, and C. Yencho, "Exploiting the use of biotechnology in sweetpotato for improved nutrition and food security: progress and future outlook," in Proceedings of the International Conference on Agro-Biotechnology, Biosafety and Seed Systems in Developing Countries, pp. 25-31, 2011.

[109] R. García, R. Morán, J. Mena et al., "Sweet potato (Ipomoea batatas L.) regeneration and transformation technology to provide weevil (Cylas formicarius) resistance. Field trial results," Developments in Plant Genetics and Breeding, vol. 5, pp. 112-117, 2000.

[110] R. Morán, R. García, A. López et al., "Transgenic sweet potato plants carrying the delta-endotoxin gene from Bacillus thuringiensis var. tenebrionis," Plant Science, vol. 139, no. 2, pp. 175-184, 1998.

[111] M. Ekobu, M. Solera, S. Kyamanywa et al., "Toxicity of seven Bacillus thuringiensis cry proteins against Cylas puncticollis and Cylas brunneus (Coleoptera: Brentidae) using a novel artificial diet," Journal of Economic Entomology, vol. 103, no. 4, pp. 1493$1502,2010$.

[112] V. A. Hilder and D. Boulter, "Genetic engineering of crop plants for insect resistance: a critical review," Crop Protection, vol. 18, no. 3, pp. 177-191, 1999.

[113] N. P. Trung, E. Fitches, and J. A. Gatehouse, "A fusion protein containing a lepidopteran-specific toxin from the South Indian red scorpion (Mesobuthus tamulus) and snowdrop lectin shows oral toxicity to target insects," BMC Biotechnology, vol. 6, article 18, 2006.

[114] H. M. M. Ibrahim, N. W. Alkharouf, S. L. F. Meyer et al., "Post-transcriptional gene silencing of root-knot nematode in transformed soybean roots," Experimental Parasitology, vol. 127, no. 1, pp. 90-99, 2011.
[115] J. F. Kreuze, I. S. Klein, M. U. Lazaro et al., "RNA silencingmediated resistance to a crinivirus (Closteroviridae) in cultivated sweetpotato (Ipomoea batatas L.) and development of sweetpotato virus disease following co-infection with a potyvirus," Molecular Plant Pathology, vol. 9, no. 5, pp. 589-598, 2008. 

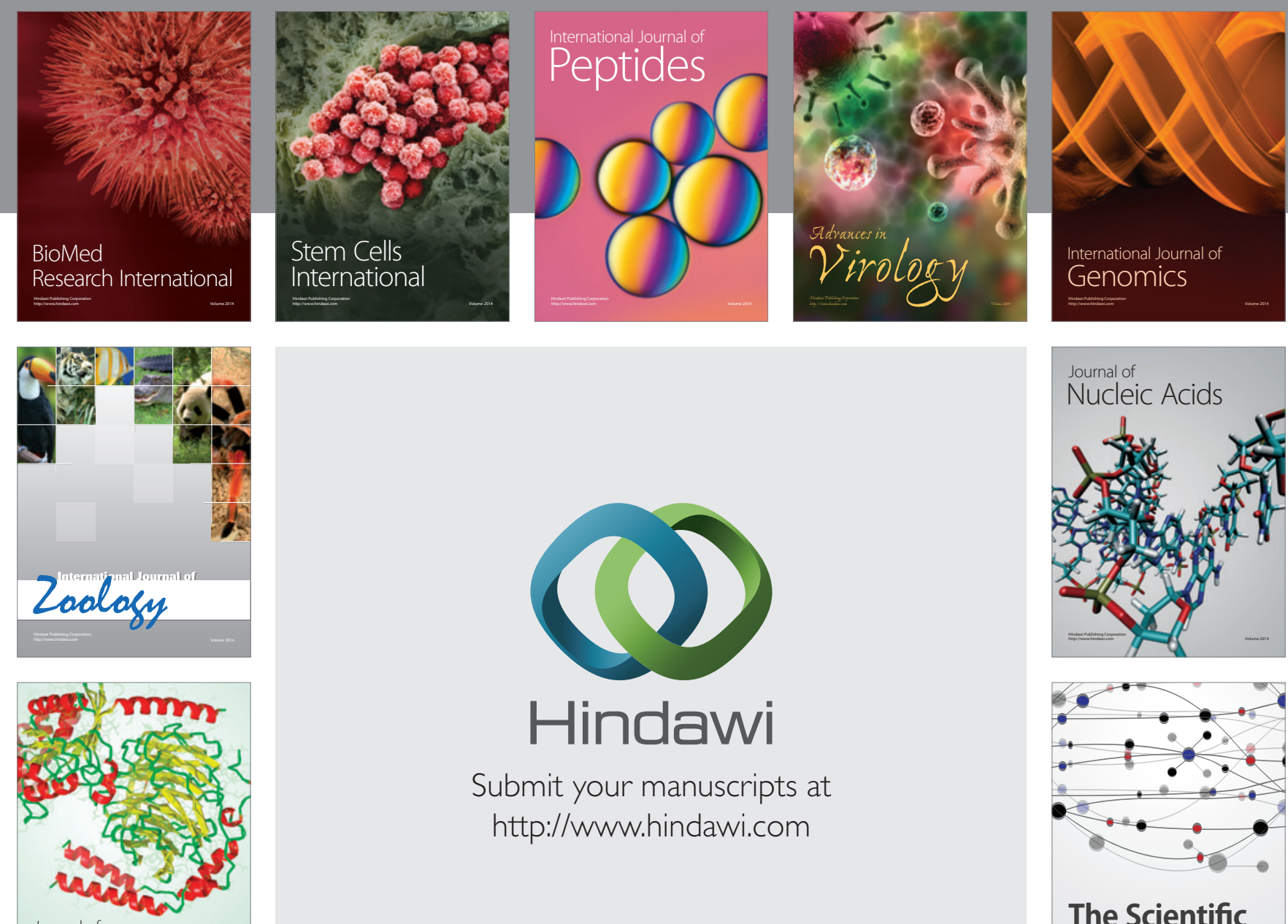

Submit your manuscripts at

http://www.hindawi.com

Journal of
Signal Transduction
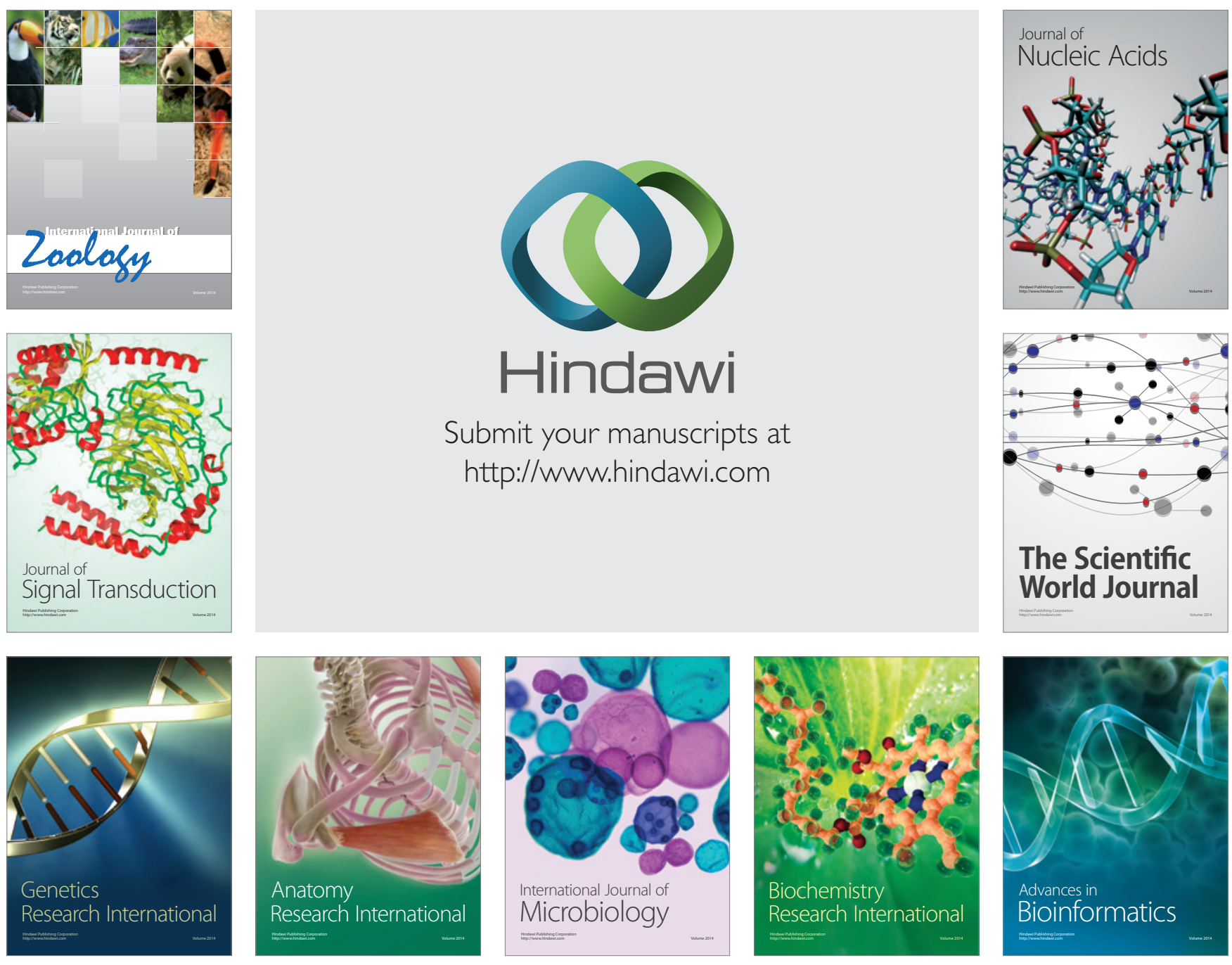

The Scientific World Journal
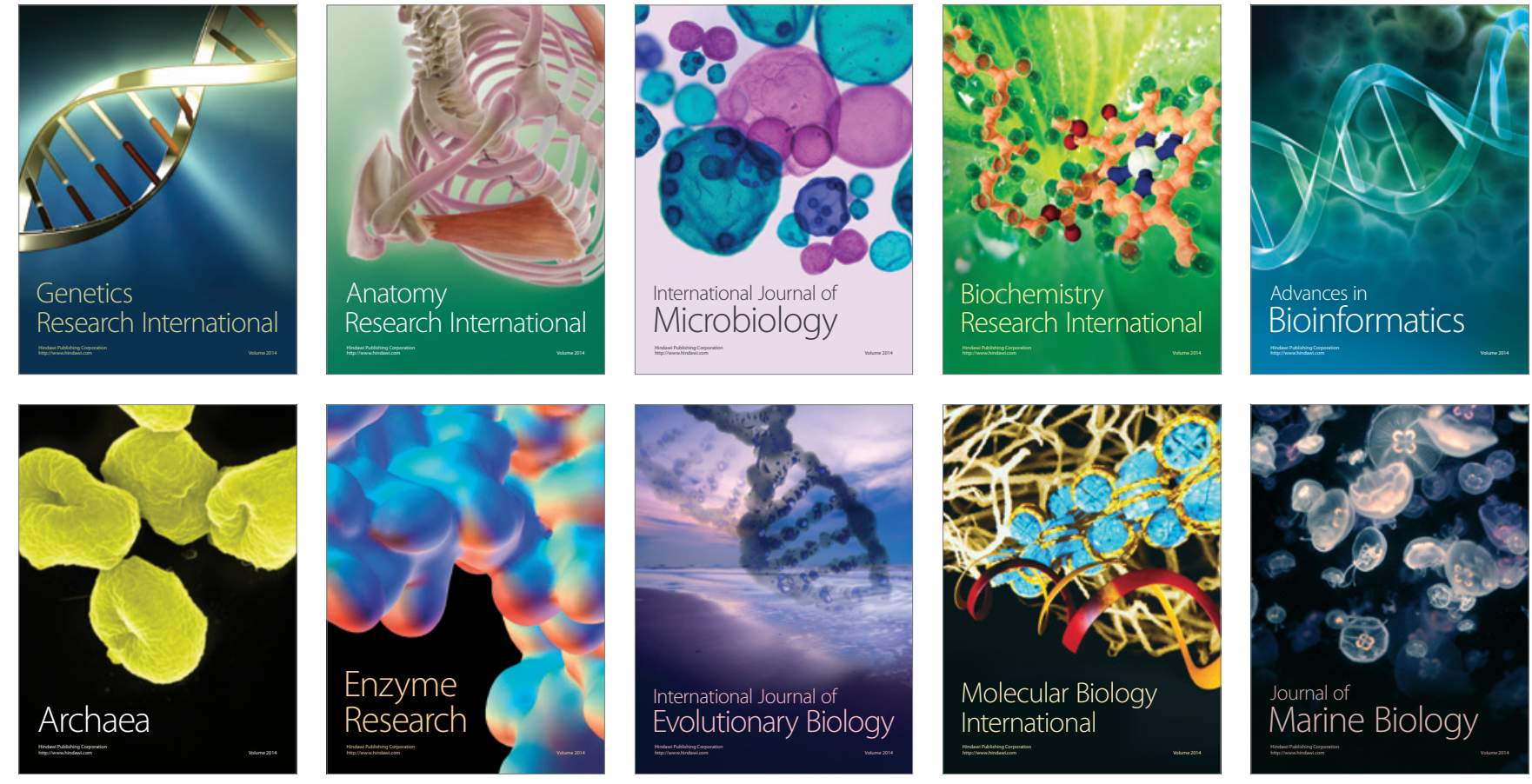